\title{
Implementasi Model Production Routing Problem With Perishable Inventory (PRPPI) dengan Kebijakan Optimize Delivery-Optimized Selling pada Produksi dan Distribusi Tempe
}

\author{
Novi Rustiana Dewi \\ Jurusan Matematika Fakultas MIPA Universitas Sriwijaya \\ Email: Novi_rustianadewi@yahoo.co.i \\ Eka Susanti \\ Jurusan Matematika Fakultas MIPA Universitas Sriwijaya \\ Email: eka_susanti@mipa.unsri.ac.id \\ Eddy Roflin \\ Program Studi Kedokteran Umum Fakultas Kedokteran Universitas Sriwijaya \\ Email: rofline@yahoo.co.id \\ Tiara Bella Octalia \\ Jurusan Matematika Fakultas MIPA Universitas Sriwijaya \\ Rika Novita \\ Jurusan Matematika Fakultas MIPA Universitas Sriwijaya
}

\begin{abstract}
Abstrak: Industri tempe Ana adalah sebuah industri rumah tangga yang berada di Kota Palembang. Tempe produksi Ana dikemas dalam tiga kemasan yaitu tempe daun, tempe plastik kepingan dan tempe plastik batangan, pada makalah ini diterapkan model PRPPI untuk jenis kemasan tempe daun. Tempe adalah salah satu produk yang bersifat mudah rusak (perishable). Penelitian ini bertujuan untuk meminimalkan biaya produksi, mendapatkan rute dan jumlah produksi tempe optimal menggunakan model Production Routing Problem Perishable Inventory (PRPPI) dengan kebijakan inventory Optimized Delivery-Optimized Selling (OD-OS). Model linier PRPPI diselesaikan menggunakan software Lingo 17. Diperoleh biaya produksi optimal adalah Rp 84.701. Rute optimal pendistribusian adalah Depot $\rightarrow$ pasar Perumnas $\rightarrow$ pasar Sekip Ujung $\rightarrow$ pasar Kebon Semai $\rightarrow$ Depot. Jumlah produksi optimal adalah 27 potong.
\end{abstract}

Kata Kunci: Model PRPPI, Optimasi biaya minimum, Kebijakan inventory OD_OS

\section{Pendahuluan}

Tempe adalah salah satu makanan khas Indonesia. Tempe sangat diminati masyarakat karena selain harganya murah dan bentuknya sederhana tempe juga mempunyai gizi yang baik, ideal untuk makanan diet, rendah kandungan lemak jenuh dan bebas kholesterol, kaya mineral dan vitamin serta dapat dikonsumsi semua kalangan umur mulai dari anak-anak hingga orang tua (Hairun dkk, 2016). Tempe termasuk kedalam produk perishable yang artinya produk tidak tahan lama atau produk mudah rusak. Tempe yang tidak terjual akan mengalami penurunan kualitas. Penurunan kualitas pada produk tempe akan mengakibatkan nilai jual menurun. Jumlah produksi tempe Ana setiap hari tidak sama, maka dari itu jumlah produksi tempe harus optimal agar tidak terjadi produksi yang berlebihan. Penentuan jumlah optimal produksi, distribusi dan inventori dapat menggunakan model PRPPI yang pertama 
kali diperkenalkan oleh Qiu et al. (2018) dalam jurnalnya dibahas tentang pembentukan model PRPPI dengan menggunakan managemen kebijakan inventory produk Perishable. Model PRPPI adalah model pengembangan dari model Production Routing Problem (PRP) yang dibahas oleh Adulyasak et al. (2015). Selain Adulyasak, PRP juga telah dibahas pada penelitian Brahimia and Aouamb (2015), dibahas masalah penggabungan formulasi PRP dengan backorder untuk multi item dan penelitian Qiu et al. (2017) tentang penggunaan metode Branch and Price pada PRP pada permasalahan emisi karbon. Pada penelitian ini akan digunakan managemen kebijakan PRPPI yaitu Optimized Delivery-Optimized Selling (OD-OS) dengan tujuan untuk mengoptimalkan biaya produksi, jumlah produksi, distribusi dan perutean pada produk tempe daun. Software Lingo 17 digunakan untuk menemukan solusi optimal model PRPPI.

\section{Model PRPPI dengan Kebijakan OD-OS}

PRP dengan perishable dapat dirumuskan sebagai berikut

$$
\min \sum_{t \in T}\left(u q_{t}+f y_{t}+\sum_{i \in N_{0}} \sum_{\tau=0} h_{i \tau t} I_{i \tau t}+\sum_{(i, j) \in A} \sum_{k \in K} c_{i j} x_{i j k t}\right)
$$

Kendala:

$$
\begin{array}{lr}
q_{t}-\sum_{i \in N} r_{i t t}=I_{0 t t} & \forall t \in T \\
\left(1-\alpha_{\tau, t-1}\right) I_{0 t, t-1}-\sum_{i \in N} r_{i \tau t}=I_{0 \tau t}, & \forall t \in T, \tau \in T_{0}, \tau \leq t-1 \\
r_{i t t}-d_{i t t}=I_{i t t}, & \forall i \in N, t \in T \\
\left(1-\alpha_{\tau, t-1}\right) I_{i \tau, t-1}-r_{i \tau t}-d_{i \tau t}=I_{i \tau t}, & \forall i \in N, t \in T, \tau \in T_{0}, \tau \leq t-1 \\
\sum_{\tau=0}^{t} d_{i \tau t}=d_{i t}, & \forall i \in N, t \in T \\
\sum_{\tau=0}^{t} r_{i \tau t}=\sum_{k \in K} r_{i t k}, & \forall i \in N, t \in T \\
q_{t} \leq c y_{t}, & \forall t \in T \\
r_{i t k} \leq Q z_{i t k}, & \forall i \in N, t \in T, k \in K \\
\sum_{i \in N} r_{i t k} \leq Q z_{0 t k}, & \forall t \in T, k \in K \\
\sum_{\tau=0}^{t} I_{i \tau t} \leq L_{i}, & \forall i \in N, t \in T \\
\sum_{j \in N_{0}} x_{i j k t}=z_{i t k}, & \forall i \in N_{0}, t \in T, k \in K \\
\sum_{j \in N_{0}} x_{i j k t}=\sum_{j \in N_{0}} x_{j i k t}, & \forall i \in N_{0}, t \in T, k \in K \\
v_{i t k}-v_{j t k}+Q x_{j i k t} \leq Q-r_{j t k}, & \forall, i \in \in N, t \in T, k \in K \\
q_{t} \geq 0, y_{t} \in\{0,1\}, & \forall t \in T \\
I_{i \tau t} \geq 0, & \forall i, j) \\
d_{i \tau t}, r_{i \tau t} \geq 0, & \forall i \in N_{0}, \tau \in T_{0}, t \in T \\
r_{i t k} \geq 0, & \forall i \in N_{0}, \tau \in T_{0}, t \in T \\
z_{i t k} \in\{0,1\}, & \forall i \in N, \tau \in T_{0}, t \in T \\
x_{i j k t} \in\{0,1\}, & \forall i \in N_{0}, t \in T, k \in K \\
r_{i t k} \leq v_{i t k} \leq Q, & \forall(i, j) \in A, t \in T, k \in K
\end{array}
$$


dengan:

$T_{0} \quad=$ himpunan periode waktu, diindeks oleh $\tau \in\{0,1, \ldots,|T|\} ;$

$K \quad=$ himpunan kendaraan, diindeks oleh $k \in\{1, \ldots,|K|\}$;

$f \quad=$ biaya tambahan produksi;

$u \quad=$ biaya produksi per unit;

$\alpha_{0 t} \quad=$ tingkat penurunan produk dari persediaan awal pada periode $t$;

$\alpha_{\tau t} \quad=$ tingkat penurunan produk yang diproduksi dalam periode $\tau$ pada periode $t$;

$h_{i 0 t}=$ holding cost pada simpul $i$ pada akhir periode $t$ untuk produk pada persediaan awal;

$h_{i \tau t} \quad=$ holding cost pada simpul $i$ pada akhir periode $t$ untuk produk yang diproduksi pada periode $\tau, 1 \leq \tau \leq|T|$;

$c_{i j} \quad=$ biaya transportasi $(i, j)$;

$d_{i t} \quad=$ jumlah produk yang laku pada simpul $i$ pada periode $t$;

$Q \quad=$ kapasitas kendaraan;

$L_{i} \quad=$ tingkat persediaan maksimum pada simpul $i$;

$C \quad=$ kapasitas produksi;

$d_{i 0 t} \quad=$ permintaan pelanggan pada pengecer $i(i \in N)$ pada periode $t(t \in T)$ yang dibayar pada persediaan awal;

$d_{i \tau t} \quad=$ permintaan pelanggan pada pengecer $i(i \in N)$ pada periode $t(t \in T)$ yang dibayar dengan produk yang diproduksi pada periode $\tau(\tau \in T)$;

$I_{i 0 t} \quad=$ jumlah persediaan pada simpul $i\left(i \in N_{0}\right)$ pada akhir periode $t(t \in T)$ yang tersisa dari persediaan awal, dan misalkan $I_{i 00}$ adalah persediaan awal simpul $i$;

$I_{i \tau t} \quad=$ jumlah persediaan pada simpul $i\left(i \in N_{0}\right)$ pada akhir periode $t(t \in T)$ yang tersisa dari produk vang diproduksi pada periode $\tau(\tau \in T)$ :

(1, Jika jumlah pengiriman produk dari persediaan awal ke pengecer $P_{i 0 t} \quad= \begin{cases} & i(i \in N) \text { pada periode } t(t \in T) \text { adalah positif; } \\ 0, & \text { Jika sebaliknya }\end{cases}$

$P_{i \tau t} \quad= \begin{cases}1, & \begin{array}{l}\text { Jika jumlah pengiriman produk yang diproduksi pada periode } \tau(\tau \in T) \text { ke } \\ \text { pengecer } i(i \in N) \text { pada periode } t(t \in T) \text { adalah positif }\end{array} \\ 0, & \text { Jika sebaliknya; }\end{cases}$

$q_{t} \quad=$ jumlah produksi pada periode $t(t \in T)$;

$r_{i 0 t}=$ jumlah pengiriman produk dari persediaan awal ke pengecer $i(i \in N)$ pada periode $t(t \in T)$;

$r_{i \tau t} \quad=$ jumlah pengiriman produk yang diproduksi pada periode $\tau(\tau \in T)$ ke pengecer $i(i \in N)$ pada periode $t(t \in T)$;

$r_{i t k} \quad=$ jumlah pengiriman ke pengecer $i$ pada periode $t$ oleh kendaraan $k$;

$v_{i t k} \quad=$ jumlah produk yang dibawa oleh kendaraan $\mathrm{k}$ sebelum mengunjungi pengecer $i$ pada periode $t$ jika pengecer $i$ dikunjungi oleh kendaraan $k$ pada 
eriode t. 0 iika tidak:

$$
\begin{aligned}
& w_{i 0 t}= \begin{cases}1, & \text { Jika permintaan pelanggan pada pengecer } i \text { di periode } t \text { terpenuhi } \\
& \text { sebagian oleh persediaan awal; } \\
0, & \text { Jika sebaliknya; }\end{cases}
\end{aligned}
$$

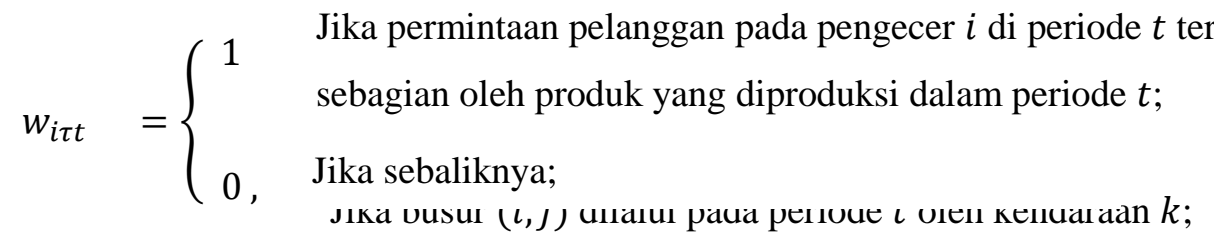

$$
\begin{aligned}
& x_{i j k t}= \begin{cases}1, & \\
0, & \text { Jika sebaliknya; }\end{cases} \\
& y_{t}= \begin{cases}1, & \text { Jika produk disiapkan untuk produksi pada periode } t \\
0, & \text { Jika sebaliknya }\end{cases} \\
& z_{i t k}= \begin{cases}1, & \text { Jika simpul } i \text { dikunjungi pada periode } t \text { oleh kendaraan } k \\
0, & \text { Jika sebaliknya; }\end{cases}
\end{aligned}
$$

Fungsi tujuan (2.1) mengukur biaya produksi, persediaan dan perutean. Kendala (2.2) dan (2.3) model alur keseimbangan produksi, persediaan dan pengiriman di depot. Kendala (2.4) dan (2.5) model alur keseimbangan persediaan, pengiriman dan konsumsi pada pengecer. Kendala (2.6) dan (2.7) mempertimbangkan komposisi permintaan dan pengiriman untuk pengecer dalam setiap periode. Kendala (2.8) memastikan bahwa variabel biner $y_{t}$ adalah satu jika produksi terjadi. Kendala (2.9) mengizinkan pengiriman positif ke simpul $i$ dalam periode $t$ hanya jika simpul ini dikunjungi pada periode $t$. Kendala (2.10) dan (2.11) memastikan batasan kapasitas kendaraan dan persediaan terpenuhi. Kendala (2.12) berfungsi sebagai kendala tingkat saat node dikunjungi. Kendala (2.13) memastikan keseimbangan alur kendaraan. Kendala (2.14) adalah kendala kapasitas untuk PRPPI. Kendala (2.15) - (2.21) bersifat non-negativitas, binaritas dan batasan jangkauan.

Asumsi asumsi yang berkaitan dengan produksi, inventory, kemunduran dan backorder adalah sebagai berikut.

1. Produksi pada setiap awal periode.

2. Persediaan pada setiap pengecer pada periode $t$ didefinisikan sebagai jumlah total produk hingga akhir periode $t$, tidak termasuk jumlah yang digunakan untuk memenuhi permintaan pada setiap pengecer pada periode $t$. Persediaan didepot pada periode $t$ didefinisikan sebagai jumlah total produk hingga akhir periode $t$, tidak termasuk pengiriman ke semua pengecer pada periode $t$. Persediaan pada periode sebelumnya diasumsikan memburuk pada periode saat ini dengan tingkat penurunan yang diketahui.

Perhatikan bahwa semakin lama produk disimpan dalam persediaan maka akan semakin cepat produk akan rusak dan juga sangat berpengaruh pada biaya penyimpanan produk. 
3. $\alpha_{\tau_{1} t} \geq \alpha_{\tau_{2} t}, \quad \forall t \in T, \tau_{1} \in T_{0}, \tau_{2} \in T_{0}, 0 \leq \tau_{1} \leq \tau_{2} \leq t$

4. $\quad h_{i \tau_{1} t} \geq h_{i \tau_{2} t}, \quad \forall i \in N_{0}, t \in T, \tau_{1} \in T_{0}, \tau_{2} \in T_{0}, 0 \leq \tau_{1} \leq \tau_{2} \leq t$

5. Backorder tidak diperbolehkan.

Untuk membatasi pilihan produk dengan periode pembuatan atau penjualan yang berbeda, kami menambahkan variabel dan kendala tambahan berikut pada formulasi PRPPI (2.1) - (2.21).

$$
\begin{array}{ll}
d_{i \tau t} \leq d_{i t} w_{i \tau t} & \forall i \in N, \tau \in T_{0}, t \in T \\
r_{i \tau t} \leq Q p_{i \tau t} & \forall i \in N, \tau \in T_{0}, t \in T \\
w_{i \tau t} \in\{0,1\} & \forall i \in N, \tau \in T_{0}, t \in T \\
p_{i \tau t} \in\{0,1\} & \forall i \in N, \tau \in T_{0}, t \in T
\end{array}
$$

Tiga kebijakan prioritas pengiriman yang terdiri dari penerapan kebijakan First Produce First Deliver (FPFD) dimana pemasok selalu mengirimkan barang yang diproduksi paling awal terlebih dahulu. Kebijakan kedua adalah sebaliknya. Di bawah kebijakan Last produce first deliver (LPFD) adalah barang yang diproduksi kemudian dikirim terlebih dahulu. Kebijakan ketiga adalah kebijakan Optimized Delivery (OD) yang ditentukan oleh model. Tiga kebijakan prioritas penjualan terkait adalah kebijakan First Produce First Sell (FPFS), kebijakan Last Produce First Sell (LPFS), kebijakan Optimized Selling (OS). PRPPI dengan kebijakan OD dapat dimodelkan dengan menambahkan kendala (2.2) -(2.21), (2.25), (2.27) dan PRPPI dengan kebijakan OS dapat dimodelkan dengan menambahkan kendala( 2.2), (2.21), (2.24), (2.26).

\section{Hasil dan Pembahasan}

Industri tempe ibu Ana adalah sebuah industri yang berada di sentra industri tempe Jln Tanjung Sari I Bukit Sangkal Kota Palembang Provinsi Sumatera Selatan. Ibu Ana memproduksi tempe setiap hari dan melakukan satu kali tahap produksi tempe. Proses produksi tempe dimulai pada pukul 13.00 WIB - 17.00 WIB. Tempe yang telah siap jual didistribusikan oleh ibu Ana menggunakan satu buah motor yang dapat menampung tempe hingga 100 tempe/jenis. Tempe tersebut dikirim kepada para pengecer yang berada dipasar Perumnas, pasar Sekip Ujung dan Pasar Kebon Semai setiap pagi pukul 06.00 WIB. Rute perjalanan untuk mendistribusikan tempe daun dimulai dari rumah ibu Ana menuju pasar Perumnas kemudian menuju pasar Sekip Ujung setelah itu kepasar Kebon Semai. Pada penelitian ini dibahas permasalahan produksi dan distribusi dengan model PRPPI untuk satu jenis tempe yaitu tempe daun.

Penelitian ini menggunakan data jenis produk dan harga jual tiap produk, data ketersediaan bahan baku, data jumlah produksi dan penjualan produksi, data biaya produksi dan biaya tambahan produksi, data distribusi produk ke tiap pengecer, data kapasitas produksi dan kendaraan serta data biaya distribusi tiap pengecer untuk periode tanggal 24 Juli 2018. Jenis-Jenis tempe dan harga jual tempe per potong disajikan pada Tabel 1. 
Tabel 1. Jumlah Produksi Tempe

\begin{tabular}{ccccc}
\hline No. & Hari & Tempe Daun & $\begin{array}{c}\text { Tempe Plastik } \\
\text { Kepingan }\end{array}$ & $\begin{array}{c}\text { Tempe Plastik } \\
\text { Batangan }\end{array}$ \\
\hline 1. & Senin & 52 & 75 & 52 \\
\hline 2. & Selasa & 39 & 82 & 52 \\
\hline 3. & Rabu & 52 & 67 & 52 \\
\hline \multicolumn{5}{l}{ Sumber : Industri tempe Ibu Ana, Juli 2018} \\
\hline
\end{tabular}

Dalam memproduksi tempe, Ibu Ana mengeluarkan biaya tambahan produksi seperti upah tenaga kerja, air, kayu bakar dan bahan bakar. Data biaya tambahan produksi disajikan pada Tabel 2.

Tabel 2. Biaya Tambahan Produksi Tempe Daun Hari Selasa

\begin{tabular}{llc}
\hline No & Tambahan & Biaya tambahan \\
\hline 1 & Upah tenaga kerja & $\operatorname{Rp~10.000,-}$ \\
\hline 2 & Air & $\operatorname{Rp~9.000,-~}$ \\
\hline 3 & Kayu Bakar & $\operatorname{Rp~8.500~}$ \\
\hline 4 & Bahan Bakar & $\mathrm{Rp} \mathrm{5.500,-}$ \\
\hline Jumlah biaya tambahan & $\mathrm{Rp} \mathrm{33.000,-}$ \\
\hline $\begin{array}{l}\text { Biaya Tambahan Produksi Tempe Daun } \\
\text { untuk per Potong }\end{array}$ & $\mathrm{Rp} \mathrm{846,-}$ \\
\hline
\end{tabular}

Tabel 3. Biaya Produksi Tempe Daun Hari Selasa

\begin{tabular}{lllll}
\hline No. & Nama Bahan & $\begin{array}{l}\text { Harga Bahan } \\
\text { (Rupiah) }\end{array}$ & Jumlah Bahan & $\begin{array}{l}\text { Biaya Produksi } \\
\text { (Rupiah) }\end{array}$ \\
\hline 1. & Kedelai & $7600 / \mathrm{kg}$ & $10 \mathrm{~kg}$ & $\operatorname{Rp~76.000,-~}$ \\
\hline 2. & Ragi Tempe & $5000 / 100 \mathrm{gr}$ & $25 \mathrm{gram}$ & $\operatorname{Rp~1.250,-~}$ \\
\hline 3. & Daun & $5000 / \mathrm{bal}$ & 3 lipat & $\operatorname{Rp~15.000,-~}$ \\
\hline \multicolumn{2}{l}{ Biaya Produksi Tempe Daun } & & $\operatorname{Rp~92.250,-}$ \\
\hline \multicolumn{2}{l}{ Biaya Produksi Tempe Daun per Potong } & $\operatorname{Rp~2.365,-}$ \\
\hline \multicolumn{2}{l}{ Biaya Tambahan Produksi per Potong } & $\operatorname{Rp~846,-}$ \\
\hline
\end{tabular}

Data jumlah produk tempe daun yang dikirim ke tiap pengecer, tempe daun yang tersisa di pengecer, dan Persediaan maksimal tempe daun di pengecer pada hari Selasa diberikan pada Tabel 4 berikut.

Tabel 4. Data Pendistribusian Tempe Daun

\begin{tabular}{lccc}
\hline & Perumnas & Sekip Ujung & Kebon Semai \\
\hline Jumlah Pengiriman & 15 & 12 & 12 \\
\hline Sisa Penjualan & 2 & 4 & 2 \\
\hline Persediaan maksimum & 35 & 30 & 35 \\
\hline Sumber : Industri tempe Ibu Ana, Juli 2018 & &
\end{tabular}

Rute yang digunakan ibu Ana dalam mendistribusikan tempe daun kepada pengecer di pasar Perumnas, pasar Sekip Ujung dan pasar Kebon Semai dapat dilihat pada Gambar 1. 


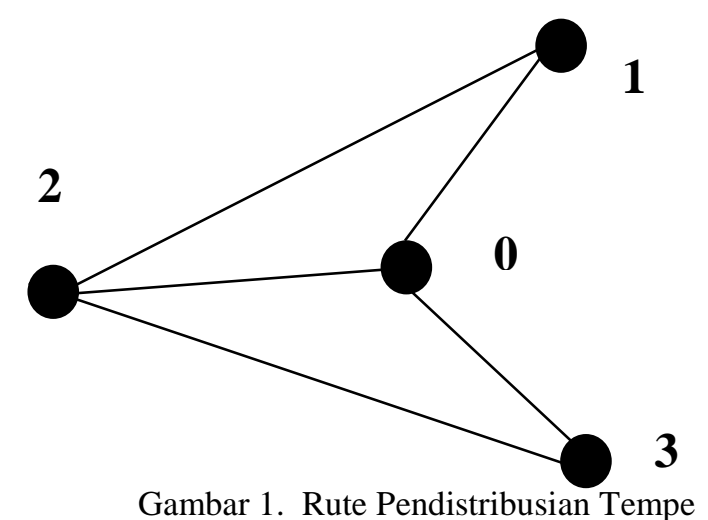

Gambar 1 menjelaskan rute pada setiap pengecer di pasar Perumnas, pasar Sekip Ujung dan pasar Kebon Semai yang dilakukan Ana. Rute pendistribusian Ana dapat digambarkan dalam bentuk graf. Simpul 0 adalah depot, simpul 1 adalah pasar Perumnas, simpul 2 adalah pasar Sekip Ujung dan simpul 3 adalah pasar Kebon Semai. Tour (perjalanan) dalam pendistribusian tempe daun ibu Ana adalah Depot - Pasar Perumnas - Pasar Sekip Ujung - Pasar Kebon Semai - Depot. Subtour yang digunakan adalah $\{(0,1),(1,2),(2,3)$, $(3,0),(0,1),(1,3),(3,2),(2,0),(0,2),(2,1),(1,3),(3,0),(0,2),(2,3),(3,1),(1,0)$, $(0,3),(3,1),(1,2),(2,0),(0,3),(3,2),(2,1),(1,0)\}$.

Data biaya transportasi yang dikeluarkan oleh Ana dalam mendistribusikan tempe daun dapat dilihat pada Tabel 5 .

Tabel 5. Biaya Transportasi Tiap Pengecer

\begin{tabular}{lcc}
\hline No. & Rute & Biaya \\
\hline 1. & Depot - Pasar Perumnas & Rp 2000 \\
\hline 2. & Pasar Perumnas - Pasar Sekip Ujung & Rp 3000 \\
\hline 3. & Pasar Sekip Ujung - Pasar Kebon Semai & Rp 2000 \\
\hline 4. & Depot - Pasar Kebon Semai & Rp 3000 \\
\hline 5. & Pasar Kebon Semai - Pasar Perumnas & Rp 5000 \\
\hline 6. & Depot - Pasar Sekip Ujung & Rp 3000 \\
\hline \multicolumn{2}{l}{ Sumber : Industri tempe Ibu Ana, Juli 2018 }
\end{tabular}

Parameter dan variabel yang digunakan pada model PRPPI diberikan pada tabel berikut

Tabel 6. Parameter dan Variabel

\begin{tabular}{cll}
\hline No. & Parameter & \multicolumn{1}{c}{ Indeks } \\
\hline 1. & $T_{0}$ & dengan $\tau=0,1$ \\
\hline 2. & $K$ & dengan $k=1$ \\
\hline 3. & $f$ & \\
\hline 4. & $u$ & \\
\hline 5. & $\alpha_{0 t}$ & dengan $t=1$ \\
\hline 6. & $\alpha_{\tau t}$ & dengan $\tau=0,1, t=1$ \\
\hline 7. & $h_{i 0 t}$ & dengan $i=1,2,3 \quad t=1$ \\
\hline 8. & $h_{i \tau t}$ & dengan $i=1,2,3 \quad \tau=0,1 t=1$ \\
\hline 9. & $c_{i j}$ & dengan $i=0,1,2,3 \quad j=0,1,2,3$ \\
\hline 10. & $d_{i t}$ & dengan $i=1,2,3 \quad t=1$ \\
\hline 11. & $Q$ & \\
\hline 12. & $L_{i}$ & \\
\hline 13. & $C$ & \\
\hline
\end{tabular}




\begin{tabular}{lll}
\hline \multicolumn{1}{c}{ Variabel } & \multicolumn{1}{c}{ Indeks } \\
\hline 1. & $d_{i \tau t}$ & dengan $i=1,2,3 \quad \tau=0,1 t=1$ \\
\hline 2. & $I_{i \tau t}$ & dengan $i=1,2,3 \quad \tau=0,1 t=1$ \\
\hline 3. & $P_{i \tau t}$ & dengan $i=1,2,3 \quad \tau=0,1 t=1$ \\
\hline 4. & $q_{t}$ & dengan $t=1$ \\
\hline 5. & $r_{i \tau t}$ & dengan $i=1,2,3 \quad \tau=0,1 t=1$ \\
\hline 6. & $v_{i t k}$ & dengan $i=0,1,2,3 \quad k=1 \quad t=1$ \\
\hline 7. & $w_{i \tau t}$ & dengan $i=1,2,3 \quad \tau=0,1 t=1$ \\
\hline 8. & $x_{i j k t}$ & dengan $i=0,1,2,3 \quad j=0,1,2,3 \quad k=1 t=1$ \\
\hline 9. & $y_{t}$ & dengan $t=1$ \\
\hline 10. & $z_{i t k}$ & dengan $i=0,1,2,3 \quad k=1 \quad t=1$ \\
\hline
\end{tabular}

\section{Model PRPPI Tempe Daun dengan Kebijakan OS-OD}

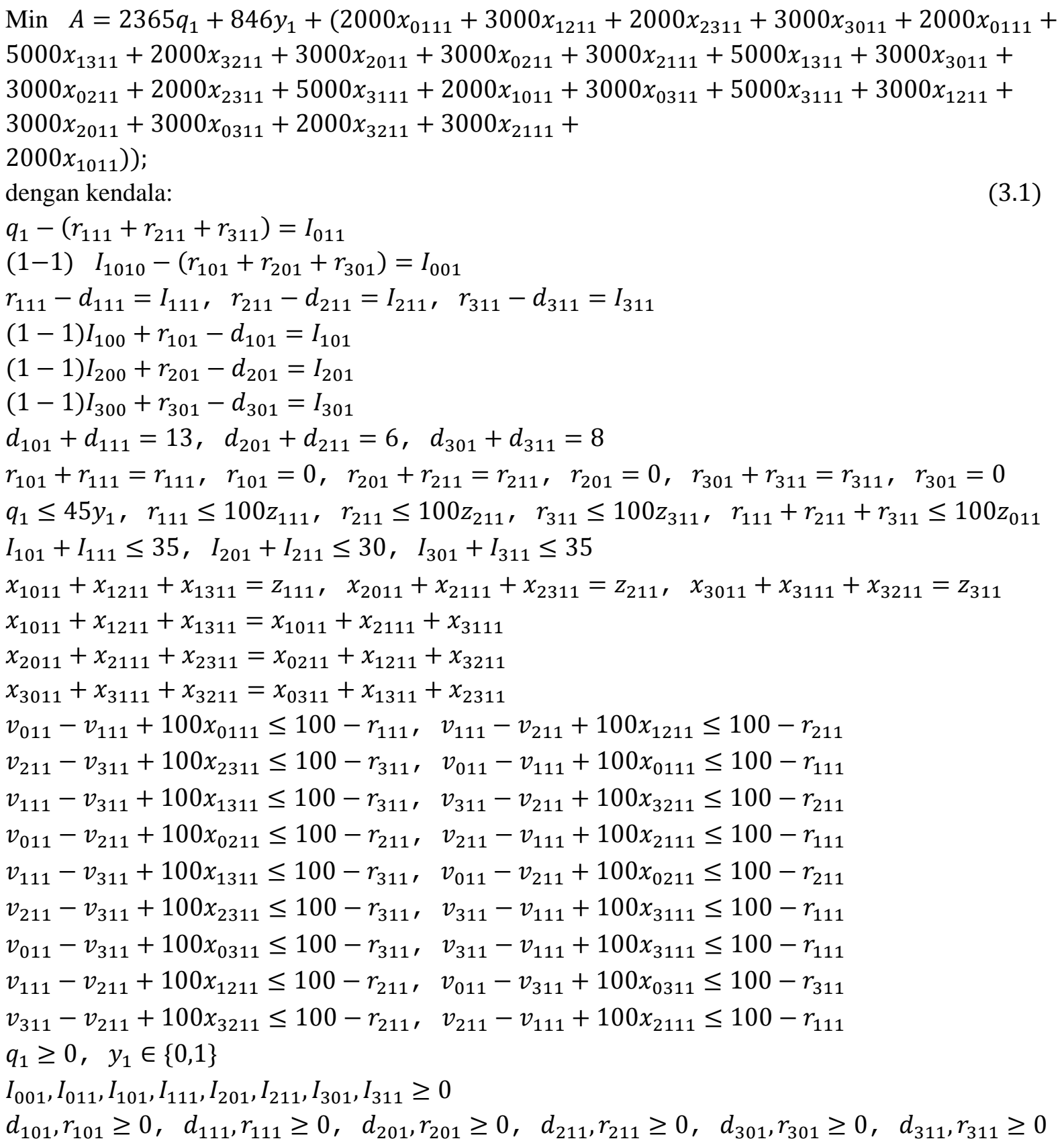




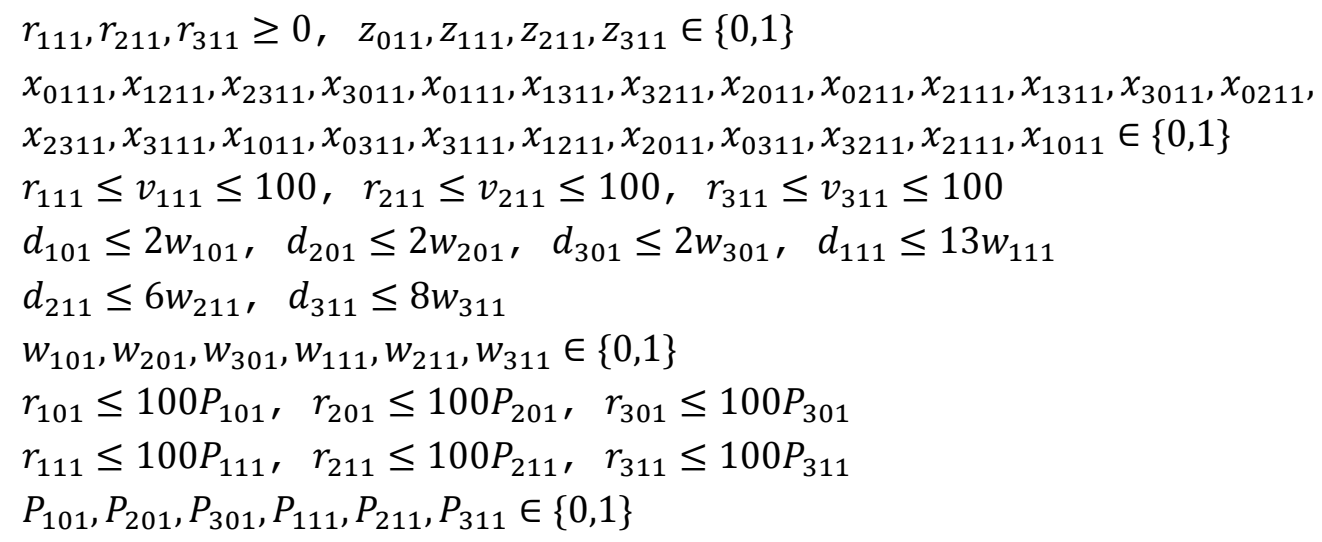

\section{Hasil Penyelesaian Permasalahan 3.1 menggunakan software Lingo 17}

$$
\begin{aligned}
& A=84.701, q_{1}=27, y_{1}=1, x_{0111}=1, x_{1211}=1, x_{2311}=1, x_{1311}=0, x_{3211}=0, x_{0211}=0, \\
& x_{2111}=0, x_{3111}=0, x_{0311}=0, x_{1011}=0, x_{2011}=0, x_{3011}=1, v_{011}=0, \\
& v_{111}=13, v_{211}=19, v_{311}=100, r_{111}=13, r_{211}=6, r_{311}=8, r_{101}=0, r_{201}=0, r_{301}=0, I_{011}=0, \\
& I_{010}=0, I_{001}=0, I_{111}=0, I_{211}=0, I_{311}=0, I_{100}=0, I_{101}=0, I_{200}=0, I_{201}=0, I_{300}=0, I_{301}=0, \\
& I_{000}=0, d_{111}=13, d_{211}=6, d_{311}=8, d_{101}=0, d_{201}=0, d_{301}=0, z_{011}=1, z_{111}=1, z_{211}=1, \\
& z_{311}=1, w_{101}=0, w_{201}=0, w_{301}=0, w_{111}=1, w_{211}=1, w_{311}=1, P_{101}=0, P_{201}=0, P_{301}=0, \\
& P_{111}=1, P_{211}=1, P_{311}=1
\end{aligned}
$$

Berdasarkan solusi model PRPPI menggunakan kebijakan OS-OD dengan Lingo 17 dapat diketahui bahwa biaya produksi tempe daun untuk model PRPPI sebesar Rp 84.701. Biaya produksi yang ibu Ana keluarkan tanpa menggunakan PRPPI adalah Rp 125.244,-Rute optimal yang terbentuk untuk pendistribusian produk tempe daun industri ibu Ana yaitu Depot $\rightarrow$ pasar Perumnas $\rightarrow$ pasar Sekip Ujung $\rightarrow$ pasar Kebon Semai $\rightarrow$ Depot. Dengan model PRPPI jumlah produksi menjadi 27 potong yang sebelumnya 39 potong.

\section{Kesimpulan}

Berdasarkan hasil dan pembahasan pada bab sebelumnya, diperoleh kesimpulan sebagi berikut.

a. Menggunakan model PRPPI dalam produksi tempe daun, ibu Ana dapat mengeluarkan biaya produksi lebih murah. Selisih biaya produksi tempe daun menggunakan model PRPPI dengan biaya produksi yang dikeluarkan ibu Ana adalah Rp 46.543.

b. Rute optimal dengan menggunakan model PRPPI adalah rute yang mendistribusikan tempe ke pengecer dari depot dilanjutkan ke pengecer dengan jumlah permintaan tempe terbanyak.

c. Ibu Ana dapat memproduksi tempe untuk periode produksi berikutnya berdasarkan jumlah produksi pada periode sebelumnya .

\section{Saran}

Bagi peneliti yang ingin melakukan penelitian selanjutnya mengenai produksi dan distribusi produk perishable disarankan dapat mengembangkan permasalahan model PRPPI dengan Kebijakan Inventory lainnya menggunakan kendaraan dan pengecer yang lebih banyak. 


\section{Daftar Pustaka}

Adulyasak, Y., Cordeau, J.-F., \& Jans, R. (2015). The Production Routing Problem: A Review of Formulations and Solution Algorithms. 141-152.

Brahimia, N., \& Aouamb, T. (2015). Multi-item production routing problem with backordering: a MILP approach. Production Research, 54(4), 1076-1093.

Gultom, S. M., Bu'ulolo, F., \& Sitepu, H. R. (2013). Penerapan Model Program Linier Primal-Dual Dalam Mengoptimalkan Produksi Minyak Goreng Pada Pt Xyz. Saintia Matematika 1(1),29-40.

Hairun, Suslinawati, \& Zuraida, A. (2016). Analisis Usaha Pembuatan Tempe (Studi Kasus Pada Usaha Pembuatan Tempe "Bapak Joko Sarwono") Di Kelurahan Binuang Kecamatan Binuang Kabupaten Tapin. Al Ulum Sains dan Teknologi, 2(1), 44-51.

Kurniawati, A. T., \& Maskur. (2015). Aplikasi Penjadwalan Ruang Kuliah Dengan Metode Integer Linear Programming Pada Ftif Itats. IPTEK, 19(2), 59-66.

Prasetyo, H., Nugroho, M. T., \& Pujiarti, A. (2006). Pengembangan Model Persediaan Bahan Baku Dengan Mempertimbangkan Waktu Kadaluwarsa Dan Faktor Unit Diskon. Jurnal Ilmiah Teknik Industri, 4(3), 115 - 122.

Purnomo, A., \& Febrian, R. (2018). Penentuan Model Dan Kebijakan Persediaan Bahan Baku (Studi Kasus : Bagian Refinery PT. Louis Dreyfus Company Indonesia Di Bandar Lampung).

Qiu, Y., Qiao, J., \& Pardalos, P. M. (2017). A branch-and-price algorithm for production routing problems with carbon cap-and-trade. Omega, 49-61.

Qiu, Y., Qiao, J., \& Pardalos, P. M. (2018). Optimal production, replenishment, delivery, routing and inventory management policies for products with perishable inventory. Omega.

Rosen, K. H. (2003). Discrete Mathematics and Its Application (Fifth ed.). Singapore: Mc. Graw Hill.

Saputra, R. (2011). Sistem Informasi Geografis Pencarian Rute Optimum Obyek Wisata Kota Yogyakarta Dengan Algoritma Floyd Warshall. Matematika, 14(1), 19-24.

Stapleton, D. M., Hanna, J. B., \& Markusen, D. (2003). Marketing Strategy Opimization: Using Linear Programming to Establish an Optimal Marketing Mixture. Marketing, 21(2), 54-62. 